\title{
Quality Characteristics of PSE-Like Turkey Pectoralis major Muscles Generated by High Post-Mortem Temperature in a Local Turkish Slaughterhouse
}

\author{
Burcu Öztürk* and Meltem Serdaroğlu \\ Ege University, Engineering Faculty, Food Engineering Department, Bornova, Izmir, Turkey
}

\begin{abstract}
The objective of this study was to investigate the effects of high post-mortem temperature application on development of pale, soft, exudative (PSE) turkey meat characteristics in terms of local slaughter conditions. Within this scope, it was targeted to obtain PSE-like muscles benefiting from different post-mortem temperature applications. Immediately after slaughter, turkey Pectoralis major ( $\mathrm{n}=15$ ) muscles were kept at various post-mortem temperatures $\left(0,10,20,30\right.$, and $\left.40^{\circ} \mathrm{C}\right)$ for $5 \mathrm{~h} . \mathrm{pH}$ values of $40^{\circ} \mathrm{C}$ treatment were lower than four other treatments $(p<0.05)$. $\mathrm{L}^{*}$ values, drip loss, cook loss, and thawing loss of $40^{\circ} \mathrm{C}$ group were higher than the other groups $(p<$ 0.05). Napole yield of $40^{\circ} \mathrm{C}$ treatment indicated that high post-mortem temperature decreases brine uptake. Protein solubility of $40^{\circ} \mathrm{C}$ group was lower than $0^{\circ} \mathrm{C}$ group $(p<0.05)$. Expressible moisture did not differ between 0 and $40^{\circ} \mathrm{C}$ treatments. Hardness, gumminess and chewiness of $40^{\circ} \mathrm{C}$ treatment were higher than $0^{\circ} \mathrm{C}$ treatment. The results of this research showed that high post-mortem temperature treatment induced development of PSE-like turkey meat, with lower $\mathrm{pH}$, paler color, higher technological and storage losses, and reduced protein solubility and texture.
\end{abstract}

Keywords: PSE, poultry, pale, soft, exudative, turkey meat

Received March 26, 2015; Revised July 13, 2015; Accepted July 20, 2015

\section{Introduction}

Pale, soft, exudative (PSE) muscle syndrome, which is characterized by low water holding capacity, soft texture and light color, is one of the most important quality issues of poultry meat. The term PSE was originally a descriptor for a pork product, characterized by light color, flaccid texture, poor water-holding capacity, and substantially reduced cook yield (Cassens, 2000; Wismer-Pedersen, 1959). Subsequently, the turkey processing industry noted meat quality problems strikingly similar to that of PSE pork (Strasburg and Chiang, 2009). Although the ultimate cause of the syndrome is not known, it appears that the combination of ante-mortem stress sensitivity of the domestic turkey and predominantly glycolytic metabolism of the breast muscle, results in accelerated rigor mortis processes, a rapid post-mortem $\mathrm{pH}$ decline and accumulation of lactic acid (Alvarado and Sams, 2002; Santos et

\footnotetext{
*Corresponding author: Burcu Öztürk, Ege University, Engineering Faculty, Food Engineering Department, 35100, BornovaIzmir-Turkey. Tel: +90-232-311-3026; Fax: +90-232-342-7592, E-mail: burcu.ozturk@ege.edu.tr
}

al., 1994; Sosnicki et al., 1998; Warriss and Brown, 1987). The consequent low $\mathrm{pH}(<5.8)$ combined with high breast muscle temperature $\left(>35^{\circ} \mathrm{C}\right)$, typically causes protein denaturation leading to soft and discolored PSE meat with reduced protein functionality (Sosnicki et al., 1998). Occurrence of PSE meat phenomenon increases the amount of purge in cook-in bags, which results in reduced cook yield, poor meat binding, and a soft product texture with poor sliceability and off-flavour (Owens et al., 2000; Poste et al., 1993). These kinds of problems could cause customer dissatisfaction and economic losses for processors (Alvarado and Sams, 2004; Foegeding, 1992).

PSE poultry meat has been associated with several factors including genetic mutation, rapid growth, muscle type, seasonal effect, environmental temperatures (ante- and post-mortem), transportation, pre-slaughter handling practices, stunning methods, acute stress just before slaughtering and post-mortem chilling temperatures (Adzitey and Nurul, 2011; Barbut et al., 2008; Bianchi et al., 2004; Lesiów and Kijowski, 2003; Mahon, 1999; McCurdy et al., 1996; McKee and Sams, 1998; Molette et al., 2003; Owens et al., 2009; Petracci et al., 2009; Solomon et al., 1998; Woelfel et al., 2002). Post-mortem temperature was found

(9)This is an open access article distributed under the terms of the Creative Commons Attribution Non-Commercial License (http://creativecommons.org/licences/ by-nc/4.0) which permits unrestricted non-commercial use, distribution, and reproduction in any medium, provided the original work is properly cited. 
to be an important processing factor affecting rigor development and overall meat quality (Alvarado and Sams, 2002). de Fremery and Pool (1960) and Khan (1971) reported that elevated temperatures (up to $37^{\circ} \mathrm{C}$ ) during poultry processing results in accelerated metabolism and a lower ultimate $\mathrm{pH}$. Rathgeber et al. (1999) reported that both rapid post-mortem glycolysis and a delay in the reduction of carcass temperature resulted in turkey breast meat with reduced ability to hold water and form stable cooked gels. A number of studies reported that high postmortem temperature treated muscles showed similar characteristics to PSE muscles (in turkey: McKee and Sams, 1998; Molette et al., 2003; Zhu et al., 2013, in broiler: Zhu et al., 2011, in pork: Liu et al., 2014).

The objective of this study was to characterize PSE-like turkey Pectoralis major muscles by evaluating the effect of post-mortem temperature in terms of local slaughter conditions. To the best of our knowledge, no studies have analyzed this phenomenon in the poultry slaughterhouses in Turkey. The chilling regimes of turkey carcasses and development of PSE meat have not been extensively based on standard methods. Additionally, with different raw material and different pre- and post- slaughter conditions, the occurrence of PSE poultry and the characteristics of PSE meat could show alterations. Therefore, the aim of this study was to validate a standard trial, which could definitely generate PSE-like turkey meat to better understand the effects of this phenomenon on turkey meat quality. For this purpose, turkey Pectoralis major muscles were subjected to different temperatures immediately after slaughter. As a consequence, the effects of high PM temperature on $\mathrm{pH}$, color, drip loss, cook loss, thawing loss, Napole yield, expressible moisture, protein solubility and texture would be discussed along the study.

\section{Material and Methods}

\section{Material}

The study was performed in a local slaughterhouse in Izmir, Aegean Region of Turkey. The fasting period started about $12 \mathrm{~h}$ before the turkeys were slaughtered. Immediately after slaughter, 75 mature male turkeys (Hybrid Converter, between 16 and $18 \mathrm{~kg}$ ) were selected on-line which had $\mathrm{pH}$ 6.0-6.3 and internal muscle temperature 42.1-43.1 ${ }^{\circ} \mathrm{C}$. As soon as Pectoralis major muscles were deboned manually from each turkey, they were packaged individually in sealed polyethylene bags and submitted to one of the five following water-bath (NÜVE BM 15/30, Turkey) temperatures: $0^{\circ} \mathrm{C}(\mathrm{T} 0), 10^{\circ} \mathrm{C}(\mathrm{T} 10), 20^{\circ} \mathrm{C}(\mathrm{T} 20), 30^{\circ} \mathrm{C}$
(T30) or $40^{\circ} \mathrm{C}$ (T40) and kept in the baths for $5 \mathrm{~h}$. The external temperatures were constantly measured and hold steady during the treatment. The $\mathrm{pH}$ values were recorded at $0 \mathrm{~min}, 20 \mathrm{~min}, 1 \mathrm{~h}, 2 \mathrm{~h}, 3 \mathrm{~h}, 4 \mathrm{~h}$, and $5 \mathrm{~h}$ post-mortem (PM). After the treatment, the samples were vacuum packaged and stored at $+4^{\circ} \mathrm{C}$ prior to analysis.

\section{Methods}

The $\mathrm{pH}$ of the muscles were measured at $0 \mathrm{~min}, 20$ min, 1 h, 2 h, 3 h, 4 h, and 5 h PM by using a pH-meter (WTW pH 330i/SET, Germany) penetration probe from three different points. The surface color of the samples were measured by using a colorimeter (CM-2600d/2500d, Konica Minolta, Germany) and expressed as Hunter L* (lightness), a* (redness), $b^{*}$ (yellowness).

Drip loss of the samples $(2.5 \mathrm{~cm} \times 2.5 \mathrm{~cm}$ size $)$ was determined according to Nortcutt et al. (1994). During the storage period of $7 \mathrm{~d}$; at $9 \mathrm{~h}, 24 \mathrm{~h}, 2 \mathrm{~d}, 4 \mathrm{~d}$ and $7 \mathrm{~d}$ PM the samples were removed from the vacuum bags, the surface was lightly blotted with a filter paper and then re-weighed. Drip loss was expressed as a percentage of the initial weight.

Cook loss was determined according to Bertram et al. (2003). After $7 \mathrm{~d}$ storage at $4^{\circ} \mathrm{C}$ in vacuum sealed bags, the samples $(2.5 \mathrm{~cm} \times 2.5 \mathrm{~cm}$ size $)$ were placed in oven bags and cooked at $150^{\circ} \mathrm{C}$ for $20 \mathrm{~min}$. Cook loss was expressed as a percentage of the pre-cooked weight.

Thawing loss was determined according to Molette et al. (2003). At $24 \mathrm{~h}$ PM, the samples $(2.5 \mathrm{~cm} \times 2.5 \mathrm{~cm}$ size) were weighed (pre-thaw weight) and frozen. They were kept at $-20^{\circ} \mathrm{C}$ for $3 \mathrm{wk}$ in vacuum sealed bags. Then, the samples were allowed to thaw overnight at $4^{\circ} \mathrm{C}$ and re-weighed. Thawing loss was expressed as a percentage of the pre-thaw weight.

Napole yield was determined according to Bertram et al. (2003). The sample was cut in pieces of about $1 \mathrm{~cm}^{3}$, weighed $\left(\mathrm{W}_{1}\right)$ and dipped in $2 \mathrm{~mL} 13.6 \%$ brine $(\mathrm{w} / \mathrm{v})(0.6 \%$ nitrite in $\mathrm{NaCl}$-in water) and remained at $4^{\circ} \mathrm{C}$ for $24 \mathrm{~h}$ in tubes. The sample in the tube was then heated for $10 \mathrm{~min}$ in $85^{\circ} \mathrm{C}$ water bath, lightly dabbed and re-weighed $\left(\mathrm{W}_{2}\right)$. Napole yield was calculated from the equation below:

$$
\text { Napole Yield }=100 \%\left\{1-\left[\left(\mathrm{W}_{1}-\mathrm{W}_{2}\right) / \mathrm{W}_{1}\right\}\right.
$$

Expressible moisture (EM) was determined according to Pietrasik and Duda (2000). The sample (approximately $0.3 \mathrm{~g}$ ) was placed on a filter paper (Whatman No:1) which was placed between two metal sheets and pressed for 1 min under 130 bar of pressure. EM was expressed as the ratio of the moisture removed from the sample to the initial moisture content. 
Protein solubility was determined according to Bradford (1976) method. The assay is based on the observation that the absorbance maximum for an acidic solution of Coomassie Brilliant Blue G-250 shifts from $465 \mathrm{~nm}$ to $595 \mathrm{~nm}$ when binding to protein occurs. Both hydrophobic and ionic interactions stabilize the anionic form of the dye, causing a visible color change. The calibration curve was arranged by using bovine serum albumin (BSA) standard with rising concentrations (10-100 mg/100 mL). The samples were centrifuged for $20 \mathrm{~min}$ at $12.000 \mathrm{rpm}$ in an extraction solution consisting of $0.3 \mathrm{M} \mathrm{NaCl}, 0.02 \mathrm{M}$ $\mathrm{KH}_{2} \mathrm{PO}_{4}, 0.02 \mathrm{M} \mathrm{KHPO}_{4}$ and $1 \mathrm{~g}$ EDTA. Then, $100 \mu \mathrm{L}$ sample was taken from the liquid phase and kindly mixed with $5 \mathrm{~mL}$ dye reactive. The absorbance was read by a spectrophotometer (Konica Minolta CM-3500d, Germany) at $595 \mathrm{~nm}$ and the protein solubility was expressed as $\mathrm{mg} / \mathrm{g}$.

Texture Profile Analysis (TPA) was performed using a texture analyzer TA-XT2 (Stable Micro Systems, Haslemere, UK). Five samples $(2.5 \mathrm{~cm} \times 2 \mathrm{~cm} \times 2 \mathrm{~cm})$ were taken from each treatment group by using a probe. Samples were compressed to $50 \%$ of its original height with a crosshead speed of $5 \mathrm{~mm} / \mathrm{s}$ and $50 \mathrm{~kg}$ load cell. The parameters calculated from the force and time curves were hardness, cohesiveness, springiness, gumminess and chewiness. Also, the samples were cut to size of $1.0 \mathrm{~cm} \times 2.0$ $\mathrm{cm} \times 0.5 \mathrm{~cm}$ for shear analysis performed with WarnerBratzer shear apparatus with a cross-head speed of $2 \mathrm{~mm} /$ $\mathrm{s}$ and a $25 \mathrm{~kg}$ load-cell.

The data was analyzed statistically by one way ANOVA and independent-samples T-Test using the SPSS for Windows statistical package program version 21.0, at a confidence interval of 95\% (Anonymous, 2012).

\section{Results}

$\mathrm{pH}$ values measured in the samples kept in different PM temperatures could be seen in Table 1 . Initial $\mathrm{pH}$ values of the samples (at 0 min PM) changed between 6.16-6.27 immediately after slaughter and no differences were recorded in $\mathrm{pH}$ values between the groups. As expected, high PM temperature significantly affected muscle $\mathrm{pH}(p<0.05)$. $\mathrm{pH}$ values were significantly lower in samples kept at $40^{\circ} \mathrm{C}$ (T40) at all evaluation periods compared to other groups $(p<0.05)$. Evaluating the effect of PM time, it was observed that $\mathrm{pH}$ values of all groups were significantly decreased till 20 min PM $(p<0.05)$, underlining the importance of $\mathrm{pH}$ decline in muscle in early PM stage.

Hunter $\mathrm{L}^{*}$ values measured in the samples kept in different PM temperatures could be seen in Table 2. L* values were significantly affected by high PM temperature and were highest in T40 samples at all evaluation periods $(p<0.05)$. Depending on the initial measurement results, $L^{*}$ values varied between 46.91-53.47, with the highest values in T40 and lowest values in T10 $(p<0.05)$. There was no significant difference between $a^{*}$ and $b^{*}$ values of the sample groups.

Drip loss measured in the samples during 7-d storage is illustrated in Fig. 1. High PM temperature had a significant effect on drip loss, since T40 had higher drip loss at all evaluation periods compared to other groups $(p<0.05)$. At $1 \mathrm{~d}$ PM, T40 had 5.64\% drip loss, while T30, T20, T10 and T0 had 3.27\%, 2.53\%, 2.38\% and 2.49\% drip loss, respectively. During $7 \mathrm{~d}$ of storage, drip loss in T40 samples were significantly increased $(p<0.05)$, even raised up to $19.61 \%$ on day 7 .

The results of cook loss, thawing loss and Napole yield of turkey breast samples are presented in Table 3. PM temperature significantly effected cook loss values $(p<0.05)$, which were highest $(34.6 \%)$ in T40. High PM temperature significantly increased thawing loss $(p<0.05)$. Thawing loss of T40 $(9.89 \%)$ was significantly higher than T0, T10, T20 and T30, with values of $1.29 \%, 1.84 \%, 3.61 \%$

Table 1. The effects of different post-mortem (PM) temperatures and duration on pH values of turkey Pectoralis major muscles

\begin{tabular}{cccccccc}
\hline \hline \multirow{2}{*}{$\begin{array}{c}\text { PM Temperature } \\
\text { Groups }\end{array}$} & \multicolumn{7}{c}{ Post-mortem time } \\
\cline { 2 - 8 } & $0 \mathrm{~min}^{2)}$ & $20 \mathrm{~min}$ & $1 \mathrm{~h}$ & $2 \mathrm{~h}$ & $3 \mathrm{~h}$ & $4 \mathrm{~h}$ & $5 \mathrm{~h}$ \\
\hline T0 & $6.16 \pm 0.18^{\mathrm{aX}}$ & $5.94 \pm 0.11^{\mathrm{aY}}$ & $5.92 \pm 0.12^{\mathrm{aY}}$ & $5.91 \pm 0.14^{\mathrm{aY}}$ & $5.92 \pm 0.14^{\mathrm{aY}}$ & $5.809 \pm 0.09^{\mathrm{aY}}$ & $5.88 \pm 0.08^{\mathrm{aY}}$ \\
T10 & $6.18 \pm 0.14^{\mathrm{aX}}$ & $5.88 \pm 0.13^{\mathrm{abY}}$ & $5.88 \pm 0.08^{\mathrm{aY}}$ & $5.88 \pm 0.07^{\mathrm{abY}}$ & $5.87 \pm 0.06^{\mathrm{abY}}$ & $5.86 \pm 0.06^{\mathrm{abY}}$ & $5.86 \pm 0.05^{\mathrm{abY}}$ \\
T20 & $6.27 \pm 0.15^{\mathrm{aX}}$ & $5.90 \pm 0.14^{\mathrm{abY}}$ & $5.89 \pm 0.11^{\mathrm{aY}}$ & $5.88 \pm 0.10^{\mathrm{abY}}$ & $5.85 \pm 0.08^{\mathrm{abY}}$ & $5.86 \pm 0.09^{\mathrm{ab}}$ & $5.86 \pm 0.09^{\mathrm{abY}}$ \\
T30 & $6.20 \pm 0.15^{\mathrm{aX}}$ & $5.84 \pm 0.12^{\mathrm{bY}}$ & $5.86 \pm 0.14^{\mathrm{aY}}$ & $5.80 \pm 0.12^{\mathrm{bY}}$ & $5.81 \pm 0.10^{\mathrm{bY}}$ & $5.79 \pm 0.14^{\mathrm{bY}}$ & $5.79 \pm 0.13^{\mathrm{bY}}$ \\
T40 & $6.26 \pm 0.16^{\mathrm{aX}}$ & $5.73 \pm 0.09^{\mathrm{cY}}$ & $5.68 \pm 0.07^{\mathrm{bYZ}}$ & $5.67 \pm 0.07^{\mathrm{cYZ}}$ & $5.65 \pm 0.07^{\mathrm{cZ}}$ & $5.65 \pm 0.07^{\mathrm{cZ}}$ & $5.65 \pm 0.06^{\mathrm{cZ}}$ \\
\hline
\end{tabular}

${ }^{1)} \mathrm{T} 0$ : Muscles treated in $0^{\circ} \mathrm{C} \mathrm{PM}, \mathrm{T} 10$ : Muscles treated in $10^{\circ} \mathrm{C} \mathrm{PM}, \mathrm{T} 20$ : Muscles treated in $20^{\circ} \mathrm{C} \mathrm{PM}, \mathrm{T} 30$ : Muscles treated in $30^{\circ} \mathrm{C}$ $\mathrm{PM}, \mathrm{T} 40$ : Muscles treated in $40^{\circ} \mathrm{C} \mathrm{PM}$.

${ }^{\mathrm{a}-\mathrm{c}}$ Means with the different letter in the same column are significantly different $(p<0.05)$.

${ }^{\mathrm{X}-\mathrm{Z}}$ Means with the different letter in the same line are significantly different $(p<0.05)$.

Table shows meanststandard deviation.

${ }^{2)}$ Initial $\mathrm{pH}$ values of the samples recorded immediately after slaughter. 
Table 2. The effects of different post-mortem (PM) temperatures and storage time on $\mathrm{L}^{*}$ values of turkey Pectoralis major muscles

\begin{tabular}{cccccc}
\hline \hline \multirow{2}{*}{$\begin{array}{c}\text { PM Temperature } \\
\text { Groups }{ }^{1)}\end{array}$} & \multicolumn{5}{c}{ Storage time (days PM) } \\
\cline { 2 - 6 } & Initial $^{2)}$ & 1 & 2 & 4 & 7 \\
\hline T0 & $49.34 \pm 0.89^{\mathrm{bX}}$ & $48.83 \pm 1.06^{\mathrm{bY}}$ & $48.86 \pm 0.43^{\mathrm{bX}}$ & $49.40 \pm 0.87^{\mathrm{bCX}}$ & $49.13 \pm 0.95^{\mathrm{bX}}$ \\
T10 & $46.91 \pm 0.29^{\mathrm{dZ}}$ & $47.31 \pm 1.20^{\mathrm{dXY}}$ & $47.73 \pm 0.61^{\mathrm{cX}}$ & $47.20 \pm 0.73^{\mathrm{dY}}$ & $47.15 \pm 0.44^{\mathrm{cYZ}}$ \\
T20 & $48.08 \pm 0.86^{\mathrm{cY}}$ & $48.63 \pm 1.19^{\mathrm{cY}}$ & $47.96 \pm 0.97^{\mathrm{cY}}$ & $48.39 \pm 1.11^{\mathrm{cY}}$ & $48.73 \pm 1.42^{\mathrm{bX}}$ \\
T30 & $49.74 \pm 1.20^{\mathrm{bX}}$ & $50.11 \pm 2.39^{\mathrm{bX}}$ & $49.47 \pm 1.35^{\mathrm{bX}}$ & $50.02 \pm 1.94^{\mathrm{bX}}$ & $49.46 \pm 1.69^{\mathrm{bX}}$ \\
T40 & $53.47 \pm 1.70^{\mathrm{aX}}$ & $53.03 \pm 1.61^{\mathrm{aX}}$ & $53.38 \pm 0.93^{\mathrm{aX}}$ & $53.06 \pm 1.98^{\mathrm{aX}}$ & $53.41 \pm 1.34^{\mathrm{aX}}$ \\
\hline
\end{tabular}

${ }^{1)} \mathrm{T} 0$ : Muscles treated in $0^{\circ} \mathrm{C} \mathrm{PM}, \mathrm{T} 10$ : Muscles treated in $10^{\circ} \mathrm{C} \mathrm{PM}, \mathrm{T} 20$ : Muscles treated in $20^{\circ} \mathrm{C} \mathrm{PM}$, T30: Muscles treated in $30^{\circ} \mathrm{C}$ $\mathrm{PM}, \mathrm{T} 40$ : Muscles treated in $40^{\circ} \mathrm{C} \mathrm{PM}$.

${ }^{\mathrm{a}-\mathrm{c}}$ Means with the different letter in the same column are significantly different $(p<0.05)$.

$\mathrm{X}-\mathrm{Z}$ Means with the different letter in the same line are significantly different $(p<0.05)$.

Table shows means \pm standard deviation.

${ }^{2)}$ Initial L* values measured after $5 \mathrm{~h}$ PM water-bath treatment period.

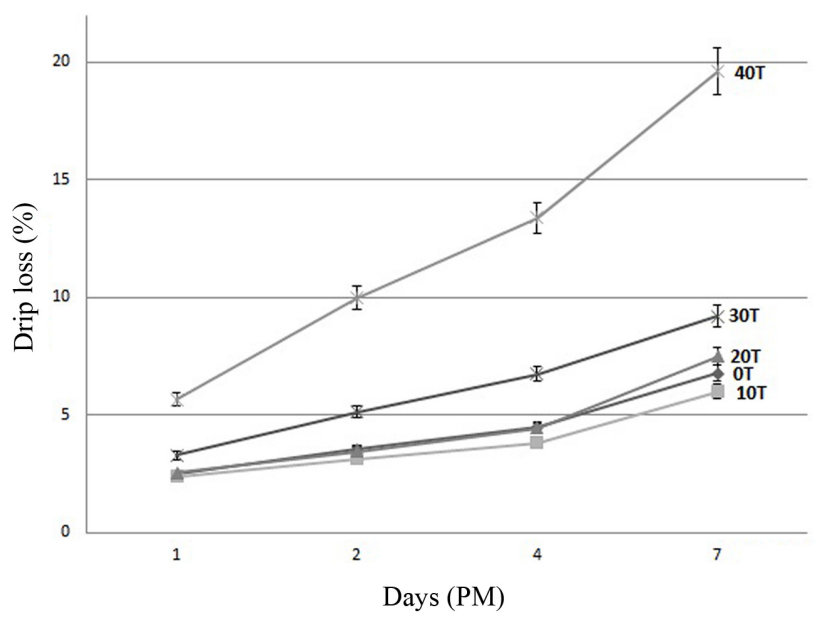

Fig. 1. Change in drip loss of different post-mortem (PM) temperature treated turkey Pectoralis major muscles during $7 \mathrm{~d}$ of storage.

and $5.08 \%$, respectively $(p<0.05)$. Napole yield was significantly decreased with high PM temperatures $(p<0.05)$. T40 had significantly lower (87.6\%) Napole yield compared with other groups, whilst the highest value (106.9\%) was in $\mathrm{T} 0(p<0.05)$.
High PM temperature did not have a significant effect on EM of the samples. At $24 \mathrm{~h}$ PM, T0 and T40 had $41.30 \%$ and $46.48 \%$ of EM, respectively. T40 had significantly lower protein solubility than $0^{\circ} \mathrm{C}(p<0.05)$, where T40 and T0 had a value of $133.71 \mathrm{mg} / \mathrm{g}$ and $141.11 \mathrm{mg} / \mathrm{g}$, respectively. The results of texture profile analysis (TPA) of the samples are presented in Table 4. In T40, hardness was higher than T0 $(p<0.05)$, indicating that high drip loss beginning from the early stages of PM could lead drying of meat prior to analysis, hence increasing hardness. T40 samples also had higher gumminess and chewiness, but lower elasticity than T0 samples $(p<0.05)$. Cohesiveness and shear force were similar between normal (T0) and PSE-like (T40) muscles.

\section{Discussion}

It is a well-known fact that $\mathrm{PM} \mathrm{pH}$ decline has tremendous impacts on technological and sensory quality characteristics of raw and processed meat. The relationship between PSE meat and $\mathrm{pH}$ implies that low muscle $\mathrm{pH}$, along with high carcass temperature in early PM, causes muscle protein denaturation (Wynveen et al., 1999). The results of this study confirm the high PM temperature

Table 3. Cook loss, thawing loss and Napole yield of turkey Pectoralis major muscles treated in different post-mortem (PM) temperatures (Cook loss and Napole yield was measured at $24 \mathrm{~h}$ PM, thaw loss was measured at 3 wk PM)

\begin{tabular}{|c|c|c|c|}
\hline PM Temperature Groups ${ }^{1)}$ & Cook Loss (\%) & Thawing Loss (\%) & "Napole Yield (\%) \\
\hline T0 & $25.29 \pm 4.72^{\mathrm{b}}$ & $1.29 \pm 0.75^{\mathrm{d}}$ & $106.90 \pm 4.57^{\mathrm{a}}$ \\
\hline $\mathrm{T} 10$ & $21.90 \pm 4.99^{\mathrm{c}}$ & $1.84 \pm 0.71^{\mathrm{d}}$ & $101.04 \pm 2.72^{b}$ \\
\hline $\mathrm{T} 20$ & $21.90 \pm 4.99^{\mathrm{c}}$ & $3.61 \pm 1.08^{\mathrm{c}}$ & $101.42 \pm 4.21^{\mathrm{b}}$ \\
\hline $\mathrm{T} 30$ & $28.27 \pm 3.49^{\mathrm{b}}$ & $5.08 \pm 1.98^{\mathrm{b}}$ & $96.68 \pm 4.24^{\mathrm{c}}$ \\
\hline $\mathrm{T} 40$ & $34.60 \pm 3.24^{\mathrm{a}}$ & $9.89 \pm 2.25^{\mathrm{a}}$ & $87.60 \pm 4.23^{\mathrm{d}}$ \\
\hline
\end{tabular}

${ }^{1)} \mathrm{T0}$ : Muscles treated in $0^{\circ} \mathrm{C} \mathrm{PM}, \mathrm{T} 10$ : Muscles treated in $10^{\circ} \mathrm{C} \mathrm{PM}, \mathrm{T} 20$ : Muscles treated in $20^{\circ} \mathrm{C} \mathrm{PM}$, T30: Muscles treated in $30^{\circ} \mathrm{C}$ $\mathrm{PM}, \mathrm{T} 40$ : Muscles treated in $40^{\circ} \mathrm{C} \mathrm{PM}$.

${ }^{\mathrm{a}-\mathrm{c}}$ Means with the different letter in the same column are significantly different $(p<0.05)$.

Table shows means \pm standard deviation. 
Table 4. Textural parameters of turkey Pectoralis major muscles treated in 0 and $40^{\circ} \mathrm{C}$ post-mortem (PM)

\begin{tabular}{ccccccc}
\hline \hline PM Temperature & \multicolumn{5}{c}{ Textural Parameter } \\
\cline { 2 - 7 } Groups $^{1)}$ & Hardness (N) & Cohesiveness & Elasticity & Gumminess & Chewiness & Shear Force (N) \\
\hline T0 & $1.68 \pm 1.05^{\mathrm{b}}$ & $0.58 \pm 0.6^{\mathrm{a}}$ & $0.27 \pm 0.1^{\mathrm{a}}$ & $0.99 \pm 0.6^{\mathrm{b}}$ & $0.31 \pm 0.32^{\mathrm{b}}$ & $21.16 \pm 6.56^{\mathrm{a}}$ \\
T40 & $5.35 \pm 5.45^{\mathrm{a}}$ & $0.56 \pm 0.7^{\mathrm{a}}$ & $0.22 \pm 0.07^{\mathrm{b}}$ & $2.96 \pm 2.91^{\mathrm{a}}$ & $0.79 \pm 0.91^{\mathrm{a}}$ & $21.02 \pm 13.93^{\mathrm{a}}$ \\
\hline
\end{tabular}

${ }^{1)} \mathrm{T} 0$ : Muscles treated in $0^{\circ} \mathrm{C} \mathrm{PM}, \mathrm{T} 40$ : Muscles treated in $40^{\circ} \mathrm{C} \mathrm{PM}$.

${ }^{\mathrm{a}, \mathrm{b}}$ Means with the different letter in the same column are significantly different $(p<0.05)$.

Table shows means \pm standard deviation.

effect on development of low $\mathrm{pH}$ values, since $\mathrm{pH}$ is one of the most important characteristics of PSE meat. Therefore, it could be concluded that lower $\mathrm{pH}$ values defined for PSE poultry meat were obtained in the samples exposed to high PM temperature. The data of previous studies verify the strong relationship between high PM temperatures and low $\mathrm{pH}$ values of poultry meat (in turkey: McKee and Sams, 1998; Molette et al., 2003; Zhu et al., 2013, in broiler: Zhu et al., 2011). Alvarado and Sams $(2002,2004)$ stated that slower chilling rates of turkey carcasses resulted in lower $\mathrm{pH}$ values.

Warris and Brown (1987) reported that the rate of $\mathrm{pH}$ decline within $1 \mathrm{~h}$ PM was the most important factor in PSE meat, with a faster decline at higher temperatures resulting in PSE pork. On the other hand, Fernandez et al. (1994) reported that ultimate $\mathrm{pH}\left(\mathrm{pH}_{\mathrm{u}}\right)$ is a good indicator of development of PSE-like meat characteristics. In our study, $\mathrm{pH}_{\mathrm{u}}$ recorded at $5 \mathrm{~h}$ PM was significantly lower in T40 compared with other groups $(p<0.05)$. Conversely, Molette et al. (2003) kept turkey muscles at 4,20 or $40^{\circ} \mathrm{C}$ and found that $\mathrm{pH}_{\mathrm{u}}$ of the samples at $24 \mathrm{~h} \mathrm{PM}$ did not differ between treatments, whilst in $40^{\circ} \mathrm{C}$ treatments this $\mathrm{pH}_{\mathrm{u}}$ value was reached earlier than in the two other groups. In this case, for a comprehensive aspect it could be suggested that early PM pH decline and ultimate $\mathrm{pH}$ should be evaluated together to identify PSE poultry meat.

Meat color is a considerable attribute for customer satisfaction since any discoloration has negative impact on customer choice. Color is an important parameter that is often used as an indicator of PSE meat (Barbut, 1993; Kauffman et al., 1993) and directly affected by $\mathrm{pH}$ and protein denaturation in the muscle. The paleness of PSE meat can be attributed to the denaturation of sarcoplasmic proteins, which increases light scattering in the muscle (Lawrie, 1991; Swatland, 1993). Higher L* values of T40 samples might be attributed to protein denaturation caused by rapid $\mathrm{pH}$ decline with high PM temperature, leading paler surface color. In some studies, $\mathrm{pH}$ and $\mathrm{L}^{*}$ values were reported to be negatively correlated parameters in PSE poultry meat (Barbut, 1993; Bianchi et al., 2005; El
Rammouz et al., 2004; McCurdy et al., 1996; Owens et al., 2000; Pietrzak et al., 1997; van Laack et al., 2000; Woelfel et al., 2002), proving the strong relationship between low $\mathrm{pH}$ and high $\mathrm{L}^{*}$ values in PSE meat. It could be suggested that since these values are pretty clear indicators of PSE meat, they could together serve as certain parameters to select PSE carcasses on-line. There have been similar studies stating accelerated PM glycolysis rate by high PM temperature leads color changes in turkey Pectoralis muscles (Alvarado and Sams, 2002, 2004; McKee and Sams, 1998; Molette et al., 2003; Rathgeber et al., 1999; Zhu et al., 2013) and in broiler Pectoralis muscles (Zhu et al., 2011). During the storage period, $L^{*}$ values of T40 samples did not change significantly, indicating that the main effect of high PM temperature on $L^{*}$ values was observed in early PM stage. Similar results were found by Molettte et al. (2003) during storage of high PM temperature treated turkey meat.

The extreme increase in drip loss may cause increased fluid expelled in package and economical losses during storage of PSE meat. High PM temperatures increase drip loss of Pectoralis muscles by affecting water-holding capacity (WHC) of meat. Exudative meat represents the last, but not the least, characteristics of PSE syndrome (Molette et al., 2003). Rapid rate of $\mathrm{pH}$ decline combined with high carcass temperatures result in denaturation of myosin and shrinkage of myosin head, drawing the thick and thin filaments closely together (Offer, 1991; Santos et al., 1994). This shrinkage results in more fluid being expelled between fibres and fibre bundles and therefore increased drip loss (Offer, 1991; Offer and Knight, 1988). The results indicated that rapid $\mathrm{pH}$ decline and myosin denaturation causing decreased water holding capacity in muscle induced higher drip loss in T40 samples, which might be a good pointer of PSE-like characteristics. Besides the denaturation and shrinkage of myosin, Puolanne and Halonen (2010) suggested that precipitation of denatured sarcoplasmic proteins could change the interaction between water molecules and thereby affect the lattice spacing and hence the drip loss. Therefore, it is a remarkable point to 
consider the combined role of myofibrillar and sarcoplasmic proteins in determining drip loss. Similar to the present study, Northcutt et al. (1994) reported that meat from chicken exposed to high temperature ( 40 to $41^{\circ} \mathrm{C}$ ) lost significant amounts of drip during the first $6 \mathrm{~h}$ PM. McKee and Sams (1998), Molette et al. (2003) and Zhu et al. (2013) found that $40^{\circ} \mathrm{C}$ PM temperature treated turkey muscles had higher drip loss compared to 20 and $0^{\circ} \mathrm{C}$. Alvarado and Sams (2002) stated that slowly or inadequately chilled turkey carcasses had increased drip loss and decreased WHC. Similar results were obtained by Zhu et al. (2011) in broiler and Liu et al. (2014) in pork.

Since PSE meat is characterized by poor water-holding capacity (WHC), the exudate accumulates as excess purge in the packages upon cooking, resulting in undesired weak texture. High cook loss results may be related to protein denaturation due to high PM temperature-low $\mathrm{pH}$ effect leading decreased WHC and increased cook loss. Santos et al. (1994) stated that the early development of rigor mortis in PSE pork combined with high carcass temperatures caused the denaturation of muscle sarcoplasmic and contractile proteins, resulted in meat with poor WHC, which was reflected by higher drip loss and cooking losses. This data was also confirmed in the present study by both higher drip and cook losses in high PM temperature treated samples. Similar to our results, some studies reported increased cook loss in poultry muscles with increased PM temperatures (Alvarado and Sams, 2002; 2004; Kong et al., 2008; Lesiak et al., 1996; McKee and Sams, 1998; Zhu et al., 2011). However, Molette et al. (2003) found no significant difference between cook loss values in turkey breast muscles treated in 0,20 or $40^{\circ} \mathrm{C}$, due to high water loss during storage prior to analysis, especially in $40^{\circ} \mathrm{C}$ group. Therefore, it could be concluded that PSE poultry meat tend to have a high cook loss mostly in the early stages of PM storage.

A high amount of poultry products is commercialized in frozen form and it has go through thawing before consumption. High thawing loss of PSE meat is another undesirable feature affecting consumer acceptability. It is known that since PSE meat has a soft texture and tend to release water, it losses high amounts of fluid during thawing. Our results support this theory as T40 had quite high thawing loss, related to high drip and cook losses occurred by decreased WHC. El Rammouz et al. (2004) stated that PSE type turkey meat had higher thawing loss than DFD type turkey meat. On the other hand, Molette et al. (2003) reported no significant difference between turkey breast muscles treated in 0,20 and $40^{\circ} \mathrm{C}$ after slaughter, in which they explained this lack of differences by the large quantities of exudate lost during the storage period (especially for $40^{\circ} \mathrm{C}$ group). Similarly, Hahn et al. (2001) found no significant difference in thaw loss between normal and rapid glycolysing turkey muscles. These contrasts could be attributed to analyse procedures used in the studies, where PM freezing time seems to have an important impact on thawing loss results.

Napole yield is an important technological quality attribute indicating the process yield after curing in brine and subsequent cooking (Bertram et al., 2003). Molette et al. (2003) stated that PSE muscles tend to have lower brining and cooking yields than normal muscles. Significant decrement in Napole yield could be attributed to high PM temperature effect on protein denaturation, affecting protein functionality negatively and leading decrease in brine uptake and cooking yield. Similar results were reported by El Rammouz et al. (2004) displaying positive relationship between $\mathrm{pH}_{\mathrm{u}}$ and Napole yield in turkey breast muscles.

Expressible moisture (EM) is the percentage of total water in meat that can be expressed by applied force which is defined as a useful measurement of WHC (Owens et al., 2000). Generally an increase in EM indicates a greater proportion of the water that is held more loosely and thus, indicates a lower WHC (Honikel and Hamm, 1994). As mentioned before, drip loss, cook loss and thawing loss of T40 were greatly higher than other groups, thus EM was also expected to be higher in T40. Since it is known that T40 samples had lost fluid rapidly till $7 \mathrm{~d}$ PM, this lack of difference in EM could be attributed to loss of extreme free water of the samples chosen for EM analyse. In a similar study, EM of turkey muscles kept in different PM temperatures did not change, although drip and cook losses were higher in high temperature treated muscles (Alvarado and Sams, 2002).

The decreased WHC of PSE meat has been associated with denaturation of myofibrillar proteins, whereas pale color is often associated with sarcoplasmic proteins (Offer, 1991). Fernandez et al. (1994) stated that slow chilling procedure in pork reduced the protein concentration in both water and salt soluble proteins. In the present study, for evaluation of functional properties of PSE-like samples, total protein solubility in the myofibrillar fraction was determined. Lower protein solubility in T40 samples was an expected result since rapid $\mathrm{pH}$ decline and high PM temperature cause muscle protein denaturation and decrease yields of PSE-like samples related to protein functionality alteration. Molette et al. (2003) and Zhu et al. (2013) obtained lower solubility of both myofibrillar 
and sarcoplasmic proteins in turkey muscles subjected to high PM temperature. On the other hand, Zhu et al. (2011) found that broiler muscles treated in high PM temperature presented a lower protein content of the sarcoplasmic protein fraction, while they represent a higher protein content of the myofibrillar protein fraction. According to researchers' point of view, this result supported that sarcoplasmic proteins were partially denatured and associated with myofibrillar proteins, by a mechanism in which they precipitated onto myofibrillar proteins. Similar results were reported by Liu et al. (2014) in pork. From this aspect, it could be suggested to investigate the behavior of both sarcoplasmic (especially phosphorylase) and myofibrillar protein fractions in PSE turkey muscles for a comprehensive observation of protein solubility.

PSE poultry meat is characterized by a soft, almost mushy texture. Since PSE meat has a low WHC, long PM storage period would lead a dry and crumbly structure with loss of fluid from the muscle. In various studies, it was reported that PSE meat has lower tenderness compared to normal meat (turkey: Barbut, 1993; Froning et al., 1978; pork: van der Wal et al., 1988). In rigor mortis development in increased PM temperatures, sarcomere shortening and hardening in texture occurs (Lawrie, 1991). Khan (1971) reported an increase in hardness in broiler muscles in increasing rigor mortis temperatures. It could be concluded that PSE-like meat had lost its elasticity and the texture had become hard-gummy which is difficult to chew in mouth. The shear force was also expected to be higher in PSE-like meat since hardness was fairly higher. However, no considerable difference was found in shear force value. Molette et al. (2003) reported no significant difference in shear force of turkey muscles between 0,20 and $40^{\circ} \mathrm{C}$ PM treated groups, while in cooked samples $40^{\circ} \mathrm{C}$ group had 2.5 times high shear force than other groups. This might be an indicator that water content and protein structure mainly influence the shear force of PSE poultry meat. On the other hand, Bilgili et al. (1989), Bianchi et al. (2005) and Zhu et al. (2011) found higher shear force in high PM temperature treated broiler muscles. Another study reported increased shear values of turkey muscles with increased PM temperature, in relation to $\mathrm{pH}$ decline, sarcomere shortening and increased drip loss (McKee and Sams, 1998).

\section{Conclusion}

The study indicated that turkey Pectoralis major muscles exposed to high PM temperature showed similar cha- racteristics to PSE meat in a local slaughterhouse of Turkey Aegean Region. $40^{\circ} \mathrm{C}$ treated muscles showed increased $\mathrm{pH}$ decline, $\mathrm{L}^{*}$ values, drip loss, cook loss, thawing loss and decreased Napole yield. The protein solubility was also lower and the texture was harder in muscles kept in high PM temperature. Depending on these results, it was indicated that high PM temperature treatment induced development of PSE characteristics in turkey. Since high PM temperature is a clear reason of PSE development, PM temperature, chilling and handling control procedures are of great importance to prevent poor meat quality problems. Besides these points, the most important quality attributes used as an indicator of PSE meat characteristics, such as $\mathrm{pH}$ and $\mathrm{L}^{*}$ values should be measured simultaneously to identify PSE meat on-line. Further research should be performed for clarifying the factors affecting PSE meat problem and explaining muscle biochemical mechanism in development of PSE poultry meat.

\section{Acknowledgements}

Authors would like to thank to Dr. Eero Puolanne from Helsinki University, Finland for providing preliminary trials and arrangements of this study and PINAR Meat Co. (Izmir, Turkey) for providing sampling material.

\section{References}

1. Adzitey, F. and Nurul, H. (2011) Pale soft exudative (PSE) and dark firm dry (DFD) meats: causes and measures to reduce these incidences-A mini review. Int. Food Res. J. 18, 11-20.

2. Alvarado, C. Z. and Sams, A. R. (2002) The role of carcass chilling rate in the development of pale, exudative turkey Pectoralis. Poultry Sci. 81, 1365-1370.

3. Alvarado, C. Z. and Sams, A. R. (2004) Turkey carcass chilling and protein denaturation in the development of pale, soft, and exudative meat. Poultry Sci. 83, 1039-1046.

4. Anonymous (2012) SPSS statistical package for windows, ver. 21.0, SPSS Inc., Chicago.

5. Barbut, S. (1993) Colour measurements for evaluating the pale soft exudative (PSE) occurrence in turkey meat. Food Res. Int. 26, 39-43.

6. Barbut, S., Sosnicki, A. A., Lonergan, S. M., Knapp, T., Ciobanu, D. C., Gatcliffe, L. J., Huff-Lonergan, E., and Wilson, E. W. (2008) Progress in reducing the pale, soft and exudative (PSE) problem in pork and poultry meat. Meat Sci. 79, 4663.

7. Bertram, H. C., Andersen, H. J., Karlsson, A. H., Horn, P., Hedegaard, J., Norgaard, L., and Engelsen, S. B. (2003) Prediction of technological quality (cooking loss and Napole Yield) of pork based on fresh meat characteristics. Meat Sci. 65, 707-712. 
8. Bianchi, M., Capozzi, F., Cremonini, M. A., Laghi, L., Petracci, M., Placucci, G., and Cavani, C. (2004) Influence of the season on the relationships between NMR transverse relaxation data and water-holding capacity of turkey breast meat. J. Sci. Food Agric. 84, 1535-1540.

9. Bianchi, M., Fletcher, D. L., and Smith, D. P. (2005) Physical and functional properties of intact and ground pale broiler breast meat. Poultry Sci. 84, 803-808.

10. Bilgili, S. F., Egbert, W. R., and Huffman, D. L. (1989) Research note: Effect of postmortem aging temperature on sarcomere length and tenderness of broiler Pectoralis major. Poultry Sci. 68, 1588-1591.

11. Bradford, M. M. (1976) A rapid and sensitive method for the quantitation of microgram quantities of protein utilizing the principle of protein-dye binding. Anal. Biochem. 72, 248-254.

12. Cassens, R. G. (2000) Historical perspectives and current aspects of pork meat quality in the USA. Food Chem. 69, 357363.

13. de Fremery, D. and Pool, M. F. (1960) Biochemistry of chicken muscle as related to rigor-mortis and tenderization. $J$. Food Sci. 25, 73-87.

14. El Rammouz, R., Babilé, R., and Fernandez, X. (2004) Effect of ultimate $\mathrm{pH}$ on physicochemical and biochemical characteristics of turkey breast muscle showing normal rate of postmortem pH fall. Poultry Sci. 83, 1750-1757.

15. Fernandez, X., Forslid, A., and Tornberg, E. (1994) The effect of high postmortem temperature on the development of pale, soft, and exudative pork: Interaction with ultimate $\mathrm{pH}$. Meat Sci. 37, 133-137.

16. Foegeding, E. A. (1992) Factors affecting texture and yield of cooked turkey. Zootechnica Int. 2, 24-27.

17. Froning, G. W., Babji, A. S., and Mather, F. B. (1978) The effect of preslaughter temperature, stress struggle anesthetization on color and textural characteristics of turkey muscle. Poultry Sci. 57, 630-633.

18. Hahn, G., Malenica, M., Müller, W. D., Taubert, E., and Petrack, T. (2001) Influence of postmortal glycolysis on meat quality and technological properties of turkey breast. Proceed. XV European Symposium on the Quality of Poultry Meat, Kusadasi, Izmir, Turkey: WPSA Turkish Branch, pp. 325-328.

19. Honikel, K. O. (2002) Biochemical and physical aspects of water holding capacity. Proceed. $3^{\text {rd }}$ Annual Pork Quality Improvement Symp., Michigan State University, East Lansing, pp. 11-16.

20. Honikel, K. O. and Hamm, R. (1994) Measurement of waterholding capacity and juiciness. In: Quality attributes and their measurement in meat, poultry and fish products. Pearson, A. M. and Dutson, T. R. (eds) Blackie Academic\& Professional, Bishopbriggs, Glasgow, UK, pp. 125-161.

21. Kauffman, R. G., Sybesma, W., Smulders, F. J., Eikelenboom, G., Engel, B., Van Laack, R. L. J. M., Hoving-Bolink, A. H., Sterrenburg, P., Nordheim, E. V., Walstra, P., and van der Wal, P. G. (1993) The effectiveness of examining early postmortem musculature to predict ultimate pork quality. Meat Sci. 34, 283-300.

22. Khan, A. W. (1971) Effects of temperature during post-mor- tem glycolysis and dephosphorylation of high energy phosphates on poultry meat tenderness. J. Food Sci. 36, 120-121.

23. Kong, F., Tang, J., Lin, M., and Rasco, B. (2008) Thermal effects on chicken and salmon muscles: Tenderness, cook loss, area shrinkage, collagen solubility and microstructure. LWTFood Sci. Technol. 41, 1210-1222.

24. Lawrie, R. A. (1991) Meat Science. 5th ed, Pergamon Press, New York, NY.

25. Lesiak, M. T., Olson, D. G., Lesiak, C. A., and Ahn, D. U. (1996) Effects of postmortem temperature and time on the water-holding capacity of hot-boned turkey breast and thigh muscle. Meat Sci. 43, 51-60.

26. Lesiów, T. and Kijowski, J. (2003) Impact of PSE and DFD meat on poultry processing-A review. Pol. J. Food Nutr. Sci. 12/53, 3-8.

27. Liu, J., Ruusunen, M., Puolanne, E., and Ertbjerg, P. (2014) Effect of pre-rigor temperature incubation on sarcoplasmic protein solubility, calpain activity and meat properties in porcine muscle. LWT Food Sci. Technol. 55, 483-489.

28. Mahon, M. (1999) Muscle abnormalities: Morphological aspects. In: Poultry Meat Science. Richardson, R. I. and Mead, G. C. (eds) CABI Publishing, New York, NY, pp. 19-64.

29. McCurdy, R. D., Barbut, S., and Quinton, M. (1996) Seasonal effect on pale soft exudative (PSE) occurrence in young turkey breast meat. Food Res. Int. 29, 363-366.

30. McKee, S. R. and Sams, A. R. (1998) Rigor mortis development at elevated temperatures induces pale exudative turkey meat characteristics. Poultry Sci. 77, 169-174.

31. Molette, C., Rémignon, H., and Babilé, R. (2003) Maintaining muscles at a high post-mortem temperature induces PSElike meat in turkey. Meat Sci. 63, 525-532.

32. Northcutt, J. K., Foegeding, E. A., and Edens, F. W. (1994) Water-holding properties of thermally preconditioned chicken breast and leg meat. Poultry Sci. 73, 308-316.

33. Offer, G. (1991) Modelling of the formation of pale, soft, exudative meat: effect of chilling regime and extend of glycolysis. Meat Sci. 30, 157-184.

34. Offer, G. and Knight, P. (1988) The structural basis of water holding in meat: general principles and water uptake in meat processing. In: Developments in meat science 4. Lawrie, R. A. (ed) Elsevier Applied Science, London, pp. 173-244.

35. Owens, C. M., Alvarado, C. Z., and Sams, A. R. (2009) Research developments in pale, soft, and exudative turkey meat in North America. Poultry Sci. 88, 1513-1517.

36. Owens, C. M., Hirschler, E. M., McKee, S. R., Martinez-Dawson, R., and Sams, A. R. (2000) The characterization and incidence of pale, soft, exudative turkey meat in a commercial plant. Poultry Sci. 79, 553-558.

37. Petracci, M., Bianchi, M., and Cavani, C. (2009) The European perspective on pale, soft, exudative conditions in poultry. Poultry Sci. 88, 1518-1523.

38. Pietrasik, Z. and Duda, Z. (2000) Effect of fat content and soy protein/carrageenan mix on the quality characteristics of comminuted, scalded sausages. Meat Sci. 40, 181-188.

39. Pietrzak, M., Greaser, M. L., and Sosnicki, A. A. (1997) Effect of rapid rigor mortis processes on protein functionality in pec- 
toralis major muscle of domestic turkeys. J. Anim. Sci. 75, 2106-2116.

40. Poste, L. M., Butler, G., Mackie, D., Agar, V. E., and Thompson, B. K. (1993) Correlations of sensory and instrumental meat tenderness values as affected by sampling techniques. Food Qual. Pref. 4, 207-214.

41. Puolanne, E. and Halonen, M. (2010) Theoretical aspects of water-holding in meat. Meat Sci. 86, 151-165.

42. Rathgeber, B. M., Boles, J. A., and Shand, P. J. (1999) Rapid postmortem $\mathrm{pH}$ decline and delayed chilling reduce quality of turkey breast meat. Poultry Sci. 78, 477-484.

43. Santos, C., Roserio, L. C., Goncalves, H., and Melo, R. S. (1994) Incidence of different pork quality categories in a Portuguese slaughterhouse: A survey. Meat Sci. 38, 279-287.

44. Solomon, M. B., Van Laack, R. L. J. M., and Eastridge, J. S. (1998) Biophysical basis of pale, soft, exudative (PSE) pork and poultry muscle: A review. J. Muscle Foods 9, 1-11.

45. Sosnicki, A. A., Greaser, M. L., Pietrzak, M., Pospiech, E., and Sante, V. (1998) PSE-like syndrome in breast muscle of domestic turkeys: a review. J. Muscle Foods 9, 13-23.

46. Strasburg, G. M. and Chiang, W. (2009) Pale, soft, exudative turkey-The role of ryanodine receptor variation in meat quality. Poultry Sci. 88, 1497-1505.

47. Swatland, H. J. (1993) Growth physiology and post-mortem metabolism in porcine muscle. In: Pork quality: genetic and metabolic factors. Puolanne, E., Demeyer, D.I., Ellis S., and Ruusunen, M. (eds) C.A.B. International, Reading, UK, pp. 115-139.

48. van der Wal, P. G., Bolink, A. H., and Merkus, G. S. M. (1988)
Differences in quality characteristics of normal, PSE and DFD pork. Meat Sci. 24, 79-84.

49. van Laack, R. L. J. M., Liu, C. H., Smith, M. O., and Loveday, H. D. (2000) Characteristics of pale, soft and exudative broiler breast meat. Poultry Sci. 79, 1057-1061.

50. Warriss, P. D. and Brown, S. N. (1987) The relationships between initial $\mathrm{pH}$, reflectance and exudation on pig muscle. Meat Sci. 20, 65-74.

51. Wismer-Pedersen, J. (1959) Quality of pork in relation to rate of pH change post mortem. J. Food Sci. 24, 711-727.

52. Woelfel, R. L., Owens, C. M., Hirschler, E. M., Martinez-Dawson, R., and Sams, A. R. (2002) The characterization and incidence of pale, soft and exudative broiler meat in a commercial processing plant. Poultry Sci. 81, 579-584.

53. Wynveen, E. J., Bowker, B. C., Grant, A. L., Demos, P. B., and Gerrard, D. E. (1999) Effects of muscle $\mathrm{pH}$ and chilling on development of PSE-like turkey breast meat. Br. Poultry Sci. 40, 253-256.

54. Zhu, X., Ruusunen, M., Gusella, M., Ylä-Ajos, M., Xu, X., Zhou, G., and Puolanne, E. (2013) High early post-mortem temperature induces activation of AMP-activated protein kinase and development of pale, soft and exudative characteristics in turkey muscles. Meat Sci. 93, 600-606.

55. Zhu, X., Ruusunen, M., Gusella, M., Zhou, G., and Puolanne, E. (2011) High post-mortem temperature combined with rapid glycolysis induces phosphorylase denaturation and produces pale and exudative characteristics in broiler Pectoralis major muscles. Meat Sci. 89, 181-188. 